\title{
Research on Existing Problems and Solutions of Teaching Skills of Ideological and Political Education in Universities*
}

\author{
Danxu Wang \\ Baicheng Normal University \\ Baicheng, China 137000
}

\begin{abstract}
Students from normal colleges and universities are the reserve force of excellent teachers. Improving and cultivating teaching skills, practical ability and comprehensive quality of normal school students majoring in ideological and political can enhance their competitiveness in employment and lay a foundation for their teaching probation, internship and becoming a qualified politics teacher in the future. Teaching skills are the essential basic qualities for students majoring in ideological and political education to be political teachers, as well as the basis and core of their professional development. From three aspects--classroom teaching design, improvement of basic skills of normal school students and multimedia teaching, this paper sums up the typical problems in the development of teaching skills of ideological and political education majors, such as lack of systematicness and coherence in designed teaching content, teaching language, teaching manner and blackboardwriting problems in terms of basic teaching skills. Specific to these problems, the paper puts forward corresponding solutions including integrating education teaching resources to improve theoretical knowledge of these normal school students; strengthening the training of teaching skills to improve their practical ability; carrying out multimedia teaching competition to improve their multimedia teaching skills. This paper aims to provide reference for the professional training and improvement of employability skills of normal school students.
\end{abstract}

Keywords-ideological and political education; teaching skills; solutions

\section{INTRODUCTION}

Teaching is an art science, whose scientificity and artistry are established based on teachers' professional knowledge and proficient teaching skills. For teachers, without extensive and profound professional knowledge, their teaching can only be a repeat of what the book says a copy of what the book says; without proficient teaching skills, their teaching cannot be called art and they cannot make the teaching activities lively and vivid to effectively improve students' learning. Teaching skill is an essential aspect for training teachers. This paper, from the perspective of training of ideological and political

*Project: This paper is a phased research achievement of the research subject "Research on Innovative Mode of Practical Training of Employability Skills of Normal School Students under the Background of Transformation" (project approval number: GH170602) subject to education science 13th FiveYear Plan Project of Jilin province. education majors in colleges and universities, explores the problems existing in students' teaching skills, hoping to help students to improve teaching skills.

\section{Classroom TeACHING DesigN}

\section{A. Lack of Systematicness and Coherence in the Designed Teaching Content}

Teaching design is a process where in order to achieve teaching objectives, teachers systematically combine various teaching factors and links so that these teaching factors and links can closely connect and integrate with each other to form a complete system. The best teaching design must be the one where all teaching factors are combined reasonably in the optimal way, and only in this way can we obtain the best teaching effect. Most students take the textbook as the blueprint and lack the integration and generalization of the textbook content. Examples they take are too simple and lack novelty and practicality most of the time. In addition, they often list many examples in one class, but the teaching content has knowledge points scattered, fails to emphasize key points and difficulties, thus lacking systematicness. Therefore, it is difficult to deepen students' impression for the knowledge.

\section{B. Singleness and Limitation in Treatment of Teaching Materials}

The analysis of specific teaching content, especially of key and difficult knowledge points, is not deep enough. On the one hand, this shows that students themselves do not wholly grasp the teaching content nor understand it thoroughly and completely. On the other hand, this also reflects the singleness and limitation in the method to deal with the teaching material content. The mechanical "reproduction" of teaching materials and auxiliary books and only following the books makes them fail to understand the status and function of teaching materials in teaching, so they lack unique and personalized understanding. 


\section{BASIC SKILLS OF NORMAL SCHOOL STUDENTS}

\section{A. Vague and Complicated Meaning and Singular Method for Asking Questions and Evaluation}

Concise, clear and definite teaching language is an important means to transfer teaching knowledge. Efficient information transfer between teachers and students can enable students to quickly understand the teaching content and save teaching time as well. Teachers, by asking students questions, can obtain a preliminary understanding of students' learning and grasp of knowledge, help students concentrate, review teaching content and adjust the teaching rate of progress. The teaching evaluation in the class and after class can better stimulate students' learning motivation, develop their interests in learning, help them build up confidence in learning and promote their development. Although many students have designed questions in a simulation classroom without students, the questions they ask are not simple and clear enough and often complicated in expression without emphasis, which reflects that they fail to deliberate over, select and design these questions. Most students adopt the mode of asking a question and answering it themselves, and their reply is often simple by saying "good", "very good", "You're right", etc., lacking feedback and evaluation on students' answers to the questions. Their expression of teaching language is monotonous, lacking large vocabulary, and professional words specific to the subject are barely used. In addition, some students, due to influence of local language, cannot distinguish blade-alveolars and retroflexes nor pronounce some words standardly.

\section{B. Over-simple Blackboard Writing Design and Poor Blackboard Writing}

Original blackboard writing design with strong logic is helpful for students to clarify teachers' teaching ideas, master key and difficult points and consolidate the teaching content, thus improving the teaching quality and effect. The blackboard writing should be clear, standard and hierarchical and should be designed according to the specific teaching content and course characteristics. All students involve blackboard writing in teaching design, but their design is often in the same form, displaying the teaching content, or reproduction of the outline in the textbook, failing to reflect the diversity and aesthetics of the blackboard writing. Moreover, there are some misspellings in some students' blackboard writing. In addition, many students write too slowly on the blackboard only to generate artistic writing, and their stroke sorting and font structure are not standard enough, so the result is not that ideal as expected.

\section{Rigid and Stiff Teaching Manner, Not Natural and Elegant Enough}

Teaching manner, together with teaching language, can play an auxiliary role in teaching. Teachers by using movements and gestures make teaching activities more lively and vivid. Teachers' good standing and walking posture, as well as encouraging gestures and looks, can attract students' attention, create a good learning atmosphere and improve students' learning effect.

In the simulation class, many students can consciously walk around and use sign language, but there are also many students who focus on looking at the computer, or look back at the projection screen, or stand in a position on the platform without moving, or make repeated exaggerated gesture. Some have wandering eyes and dare not look straight, some are poker-faced or flushed with nervousness, which makes the whole teaching process not smooth, natural, lacking awareness to interact and communicate with students.

\section{Multimedia TeAching}

\section{A. Paying Too Much Attention to the Form in the Production of Multimedia Courseware, Which Wasts Time and Energy}

Some students produce multimedia teaching courseware with overcomplicated section of layout, color, contrast and switching mode, which makes students in the class pay too much attention to the courseware production skills instead of the teaching content, so this distract students' attention and affect the teaching effect. In addition, some teachers often pay too much time and energy make the teaching courseware perfect, but ignore the research on teaching method, just like putting the cart before the horse.

\section{B. Multimedia Courseware Is a Simple Copy of Lecture Notes}

When using multimedia in teaching, many students input all the content of the course into the page, regardless of the primary and secondary contents or details and omissions, and there is any skill in transition of knowledge points. This not only make students unable to grasp the outline of the teaching content when they watch the PPT, but also make students feel disgust for the teaching due to the vapidity of "teaching based on reading teaching content and improper attitude, so we can imagine what the teaching effect will be.

\section{Simple "Bringism"}

Courseware design is simple in the form. The courseware only presents the text content, and due to too many words, the font is small, and due to lacking display of pictures, the courseware fails to reflect vivid deign and combination. In the selection of video and audio materials, on the one hand, such materials selected are too few, and on the other hand, the editing and adjustment skills are not skilled enough.

\section{THE WAYS to IMProve the TEACHING SKILLS OF IDEOLOGICAL AND POLITICAL EDUCATION MAJORS}

\section{A. Improving Teaching Design Level and Innovation Ability}

Teaching design level and the corresponding innovation ability shall be improved from two aspects: first, according to the requirements of the Ministry of Education and the university for normal students, the university shall not be limited by theoretical courses in formulating training scheme, and shall set professional extension courses combining theory with practice to improve the design ability of students. In terms of textbook selection, the university shall update the textbooks of teaching design used by normal school students in time. Schools and departments can purchase new supplementary teaching materials for students to broaden students' 
educational theory knowledge and help them better understand the front and dynamic contents of academic research; second, the university may invite front-line teachers teach teaching skills courses, so that students can absorb practical and applicable teaching experience, and allow students to enter the middle school and high school classrooms to observe the teaching of the teachers there so as to obtain more experience in the application of teaching design in the classroom. In addition, teachers should actively create an atmosphere of innovation in classroom teaching design and impart group cooperative learning, classroom discussion method and heuristic method to students to enhance their enthusiasm for innovation.

\section{B. Strengthening the Training of Basic Skills of Normal School Students}

1. Teaching language skills: Language is a bridge of communication between people, and teaching language is one of the necessary ways to impart knowledge to students.

Both the introduction and teaching in classroom are inseparable from the support of teaching language. The review of current politics in 5 minutes before class, the discussion in class, the daily debate competition, speech contest and reading contest can build up the psychological quality of normal school students so that they can express their opinions clearly, accurately and fluently in front of people. At the same time, lecturing, interpretation and practice acceptance contests are also helpful for students to improve their teaching language skills. In teaching, questions should be expressed accurately so that students can understand and master the key points, and should center on the key points or difficult points of the teaching content. In addition, teachers when asking students questions shall use vivid language and express clearly, and shall consider students' interests and motivation. The questions shall be difficult to some extent but the difficulty level shall be appropriate. Therefore, when carrying out question design practice, normal school students should, according to students' cognitive level, design question links including understanding, applying, analyzing and evaluating the questions. These stratified and deep questions can cause students to think, help them develop consciousness of asking questions in question and solve specific historical problems in question, so as to master the skills to solve problems.

2. Teaching manner skills: Teachers, as role models for students, should pay attention to their own words and manners to leave a good image in the minds of students. The improvement of teachers' charm is a systematic engineering, including self-training, imitation, mirror practice and micro standard methods. The four methods are not parallel, but interspersed with each other and sometimes, they are integrated together for use. In the process of listening to lectures and observation, normal school students should pay attention to learning from excellent teachers, and can simulate some behaviors in their own classroom and then determine to accept or reject such behaviors according to their own situations.

3. For blackboard writing design and blackboard writing, the schools shall make the standard blackboard writing as a daily requirement, work out a daily training plan, and carry out internal evaluation and comparison within the department regularly, so that the blackboard writing of normal school students can reach a certain specific standard, such as nice and neat. On this basis, strengthen the integration of the blackboard writing with textbook, its dependence with teaching language and strengthen irregular training. In the teaching design, normal schools shall strengthen and attach importance to the training of blackboard writing.

\section{Strengthening Multimedia Teaching Means and Courseware Making Ability}

Before making multimedia courseware, normal school students should be given systematic theoretical education and provided with corresponding teaching materials. Schools shall avoid large class capacity and shall adopt small class for teaching to the greatest extent. Teaching design shall combine with PPT making. Teaching courseware is not the dull display of knowledge, and shall not include excessive videos and music. The PPT designed shall be aesthetically pleasurable and conform to the topic of the subject at the same time. In addition, when using online courseware resources for reference, normal school students shall make corresponding change according to the characteristics of the students and the depth and breadth of course content to realize individualized teaching. In this way, they can stimulate students' Interaction and resonance. Moreover, when using PPT in classroom, normal school students shall not blindly copy and read the PPT content, but shall grasp the course and make the PPT a supplementary means for teaching.

\section{CONCLUSION}

At school, students have a good professional quality and solid teaching skills; when leaving school, they can quickly adapt to education teaching work, and use various teaching means, methods and skills skillfully to control the classroom and teach students. The development of ideological and political education majors is not only related to the improvement of their personal value, but also affects the development of students and education career. Teaching skills cannot be improved overnight. We should actively look for problems in practice, explore ways and methods to improve teaching skills, intensify teaching reform, and truly realize self-value in teaching practice. Of course, it is a long-term and arduous task to train professional teaching skills of normal school students, and this requires us to constantly explore, practice and reform the training methods and approaches in future work practices. Both pre-service and post-service training are all necessary links for professional development of teachers. Normal universities and colleges should also grasp the opportunity to reform the talent training program and highlight practicality and development, so as to better promote the training of talents majoring in teacher education.

\section{REFERENCES}

[1] Yang Ya, Hu Xiaolei, Jiang Hao,Wang Yu, He Juying. Influence of Combination of Multiple Evidence-based Teaching Methods on 
Students' Behaviors and Skills in Solving Problems [J]. China Higher Medical Education, 2016(10)99-100. (in Chinese)

[2] Ma Yongmei, Hu Chuanshuang. Research on Problems and Countermeasures of Normal College Students' Teaching Skill Training [J]. Journal of Huaibei Professional and Technical College, 2012(4)4243. (in Chinese)

[3] Chen Qirui. First Exploration on Problems in Professional Teaching Skills of Normal school students [J]. Journal of Sanming University, 2000(4)79-81. (in Chinese)

[4] Zhang Hui. Problems in Teaching Skills of Ideological and Political Education Normal Students and Relevant Enlightenment [J]. Course Education Research, 2018(48)74-75. (in Chinese)

[5] Qin Dongfang, Wang Chun, Wang Lan. Construction and Practice of the "Four-dimensional" Vocational Skills Training System for Normal College Students - Taking Ma'anshan Teacher's College as an Example. Journal of Shaanxi Institute of Education, 2018(09)56-58. (in Chinese)

[6] Lin Cuiying. Strengthening Training of Vocational Skills of Normal School Students to Develop Their Vocational Ability [J]. Journal of Liuzhou Teachers' College, 2010(05):98-99 . (in Chinese) 